dr inż. Janusz, Biliński

mgr inz. Sylwester Buta

mgr inz. Emil Gmurczyk

mgr inz. Jerzy Kaska

dr inz. Tadeusz, Platek

MEDCOM

\title{
Asynchroniczny napęd $z$ hamowaniem odzyskowym do elektrycznego zespołu trakcyjnego serii EN57 AKM
}

\begin{abstract}
$W$ artykule przedstawiono asynchroniczny napę z hamowaniem odzyskowym do elektrycznego zespołu trakcyjnego serii EN57. Omówiono budowę napędu, przedstawiono charakterystyki trakcyjne i symulacje zużycia energii. Przedstawiono wyniki uzyskane z jazd próbnych, ilustrujace efekty odzysku energii podczas hamowania pojazdu. W podsumowaniu omówiono korzyści wynikajace z zastosowania hamowania elektrodynamicznego.
\end{abstract}

\section{Wstęp}

Od kilkunastu lat jest wdrażany program modernizacji elektrycznych zespołów trakcyjnych serii EN57. Cele jakie przyświecają modernizacji to podniesienie komfortu pasażerów, podniesienie parametrów eksploatacyjnych (zmniejszenie awaryjności, ułatwienie obsługi), spełnienie norm technicznych (w szerokim rozumieniu), przedłużenie okresu eksploatacji taboru pasażerskiego, optymalizacja kosztów obsługi i eksploatacji. Optymalnym okresem do przeprowadzenia modernizacji jest zwykle połowa planowanego całkowitego okresu ,życia” taboru.

W bieżącym roku jest realizowana modernizacja napędu ezt $\mathrm{z}$ wykorzystaniem silnika asynchronicznego. Projekt ten został zainicjowany przez ZNTK „Mińsk Mazowiecki” we współpracy z firmami MEDCOM (falownik) i EMIT Żychlin (silnik trakcyjny). Zastosowanie napędu tego typu pozwala na wyeliminowanie najbardziej dotkliwego problemu zespołów trakcyjnych - zbyt małej mocy napędu, ograniczającej zarówno przyspieszenie rozruchu jak i prędkość maksymalną. Parametry te zaczynają być problemem przy organizacji ruchu na liniach zmodernizowanych do $160 \mathrm{~km} / \mathrm{h}$ i znacznie obciążonych odcinkach linii głównych o ruchu mieszanym. Wprowadzenie silników prądu przemiennego pozwoliło na blisko dwukrotne zwiększenie mocy napędu, co umożliwiło podniesienie prędkości maksymalnej EN57AKM do 120 $\mathrm{km} / \mathrm{h}$ (ograniczonej konstrukcją mechaniczną wózka, a nie możliwościami napędu) oraz uzyskanie przyspieszenia rozruchu $1,0 \ldots 1,2 \mathrm{~m} / \mathrm{s}^{2}$, opóźnienia hamowania ok. $0,9 \mathrm{~m} / \mathrm{s}^{2}$, porównywalnych $\mathrm{z}$ wartościami przyspieszeń uzyskiwanych przez zespoły trakcyjne nowej generacji. Niemniej ważne jest zastąpienie klasycznego rozruchu rezystorowego rozruchem częstotliwościowym z rekuperacją energii, co w warunkach bardzo częstych zatrzymań w ruchu regionalnym - a szczególnie aglomeracyjnym - przynosi znaczące

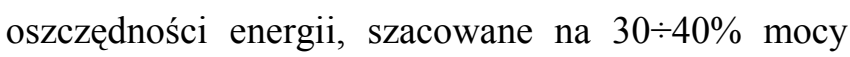
zużywanej aktualnie na cele trakcyjne zespołu. Układ falownikowy umożliwia zastosowanie hamowania odzyskowego i uzyskanie pełnej współpracy z systemem hamulca pneumatycznego (blending). System sterowania jest wyposażony w funkcję eliminacji poślizgu podczas rozruchu i hamowania, zapewniająca ograniczenie zużycia obręczy i klocków hamulcowych (zmniejszenie kosztów oraz zmniejszenie stopnia zanieczyszczenia torowisk opiłkami żeliwnymi) jak i zauważalne obniżenie poziomu hałasu podczas hamowania.

\section{Układ napędowy z falownikami HV IGBT}

Falowniki FT-500-3000-UF do EN57 zostały wykonane w technologii HV IGBT 6,5 kV. Schemat blokowy układu napędowego jest przedstawiony na rysunku 1

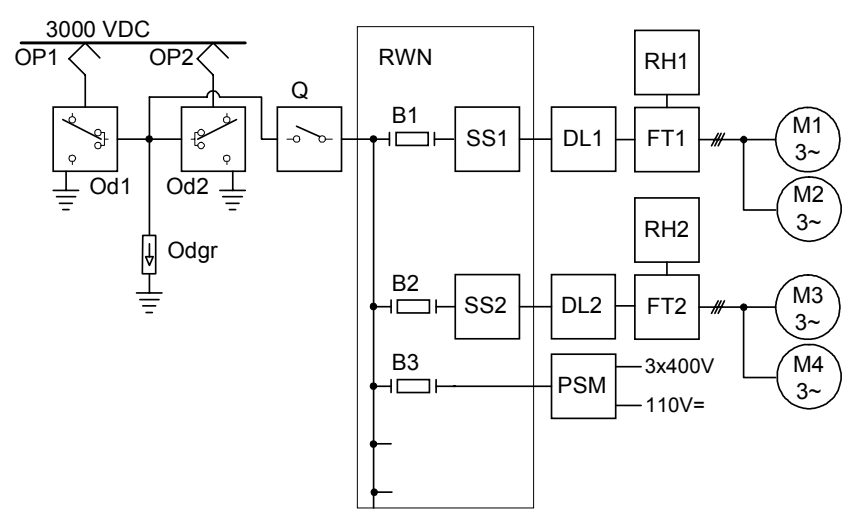

Rys. 1 Schemat blokowy układu napędowego: OP1, OP2 - odbierak prqdu, Od1, Od2 - odtacznik trakcyjny, $Q-$ wytacznik szybki, Odgr-odgromnik, $R W N$ - rozdzielnia wysokiego napięcia, 


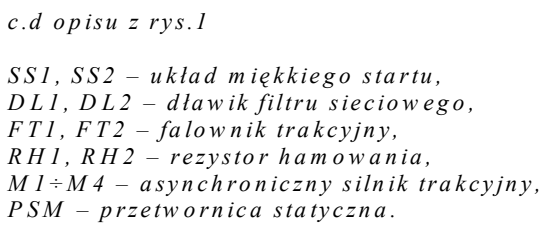

Zmodernizowany elektryczny silnik trakcyjny prądu przemiennego STDa 315 X6EN produkcji EMIT Żychlin - wyposażony w czujnik prędkości i czujnik temperatury - został umieszczony w zmodyfikowanym korpusie silnika trakcyjnego prądu stałego typu Lk-450. Asynchroniczny silnik trakcyjny ma dwukrotnie większą moc - moc znamionowa wynosi $250 \mathrm{~kW}$, natomiast moc godzinna $300 \mathrm{~kW}$. Zarówno silniki, jak i przekształtniki tranzystorowe oraz dławiki sieciowe są chłodzone powietrzem z wymuszeniem zewnętrznym.

Napęd FT500-3000-UF umożliwia rozruch, jazdę $\mathrm{z}$ zadanym momentem, jazdę $\mathrm{z}$ zadaną prędkością (tempomat), wybieg oraz hamowanie pojazdu, także przy nastawionym kierunku jazdy do tyłu. Układ jest przystosowany do współpracy $\mathrm{z}$ rejestratorem napięcia trakcji i parametrów falownika, który pozwala na odtworzenie warunków zasilania w przypadku zakłóceń w pracy lub podczas awarii układu napędowego. Został także wprowadzona trybu pracy jazdy wielokrotnej, by zapewnić wysoki poziom elastyczności konfiguracji eksploatacyjnej.

Charakterystyki trakcyjne ezt EN57AKM przedstawiono na rysunku 2.

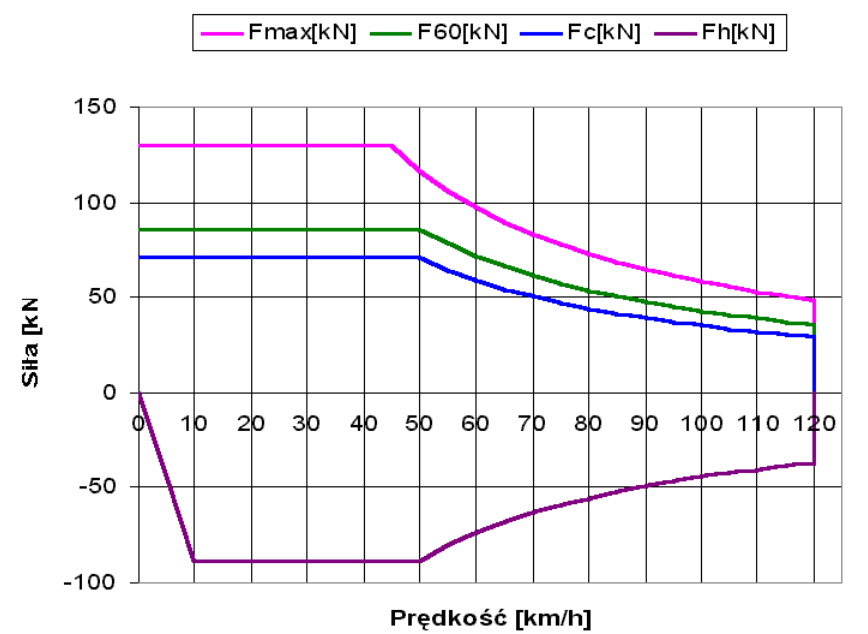

Rys. 2. Charakterystyki trakcyjne ezt EN57 AKM.

Fmax- siła pociagowa maksymalna odniesiona do osi zestawów napędnych dla ,3 min” mocy silników trakcyjnych, F60 - sita pociagowa odniesiona do osi zestawów napędnych dla godzinnej mocy silników, Fc-Sita napędowa odniesiona do osi zestawów napędnych dla ciagtej mocy silników, Fh - siła hamowania odniesiona do godzinnej mocy silników trakcyjnych

Widok zabudowanego zespołu napędowego przedstawiono na rysunku 3.

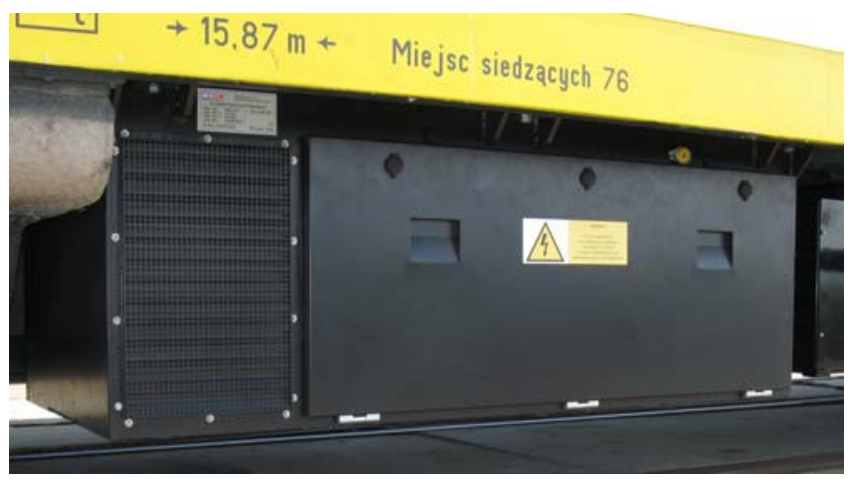

Rys. 3.Widok zespołu napędowego.

\section{Hamowanie pojazdu}

Hamowanie elektrodynamiczne (ED) działa w trzech obszarach: stałej mocy (określonej przez moc silników trakcyjnych), stałego momentu hamującego (przy prędkości powyżej $10 \mathrm{~km} / \mathrm{h}$ ) i blendingu współpracy hamulca elektrodynamicznego i pneumatycznego $\mathrm{w}$ zakresie prędkości od $10 \mathrm{~km} / \mathrm{h}$ do zatrzymania zespołu trakcyjnego. Maksymalne napięcie w sieci jezdnej podczas rekuperacji przy hamowaniu ED zostało ustalone na $3900 \mathrm{~V}$ - po przekroczeniu tej wartości napięcia energia jest tracona w rezystorze hamowania.

Układ hamowania odzyskowego został tak zaprojektowany, by również w szczególnych warunkach układ zachował zdolność do pracy. W przypadku wjazdu hamującego elektrodynamicznie zespołu na zwarty odcinek zasilania, zabezpieczeniem jest zadziałanie wyłącznika szybkiego, odłączającego zasilanie zespołu trakcyjnego.

System hamowania elektrodynamicznego jest objęty pokładowym systemem diagnostycznym. Maszynista ma możliwość uzyskania informacji o stanie systemu. Widok okna diagnostycznego hamulca na terminalu maszynisty przedstawiono na rysunku 4.

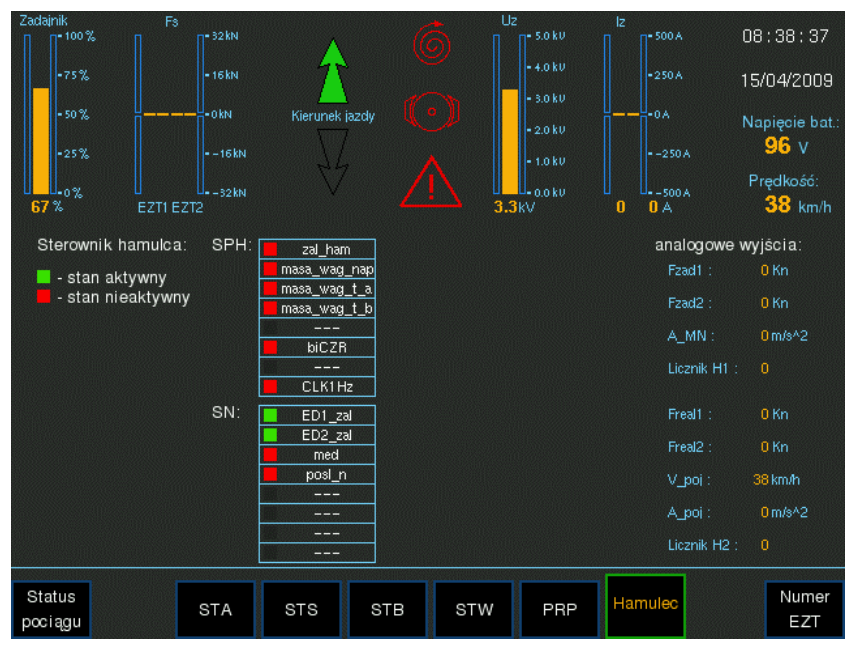

Rys. 4. Okno diagnostyczne sterownika hamulca na terminalu maszynisty 


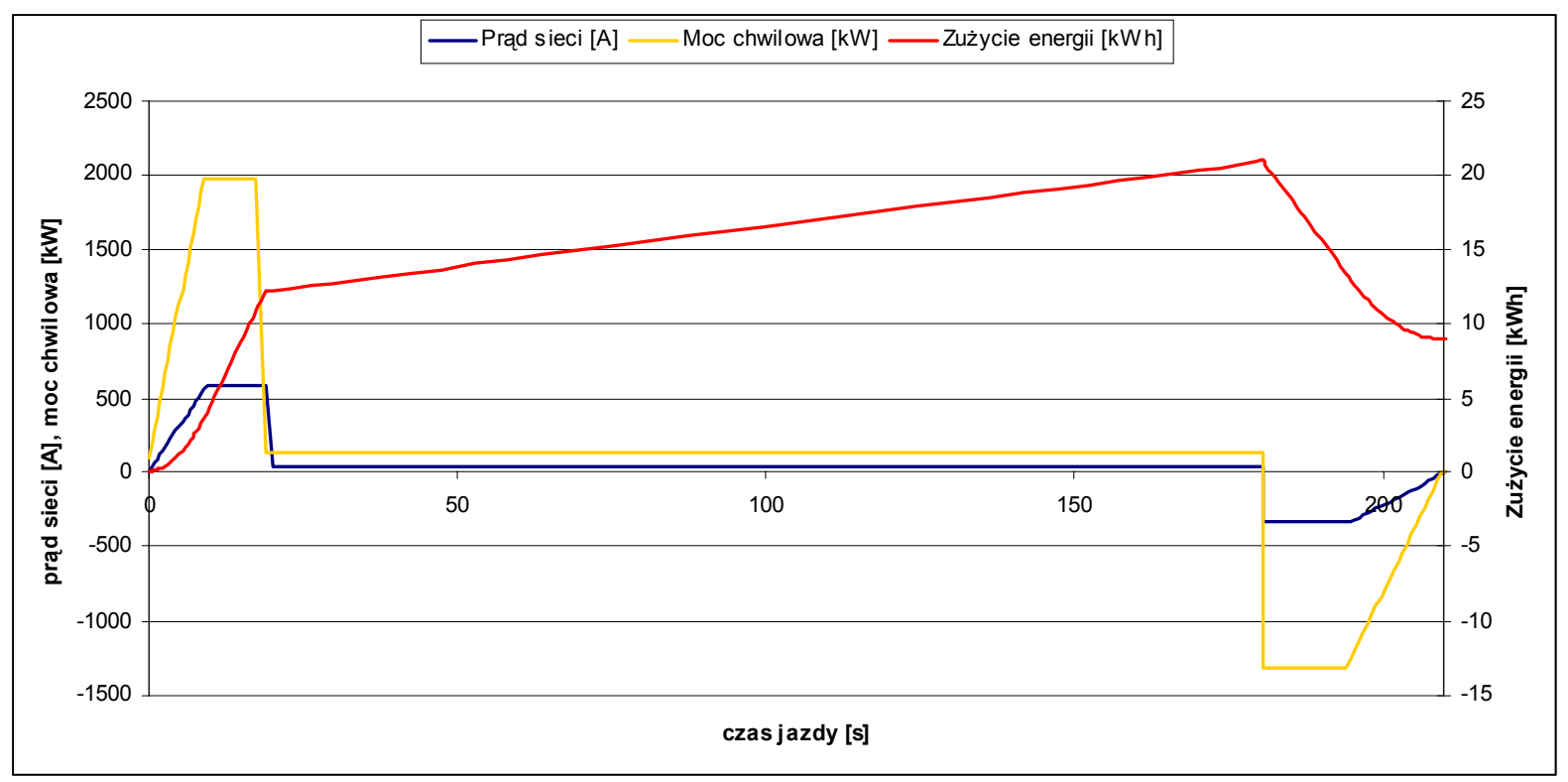

Rys. 5. Obliczenia teoretyczne jazdy i hamowania elektrycznego zespołu trakcyjnego z napędem asynchronicznym.

Maszynista otrzymuje informacje o zadanej sile hamowania na obwodzie koła jezdnego przez silniki pierwszego i drugiego wózka napędnego (Fzad1, Fzad2), opóźnieniu zadanym za pomocą manipulatora hamulca (A_MN), realizowanej sile hamowania na obwodzie koła jezdnego przez silniki pierwszego i drugiego wózka napędnego (Freal1, Freal2), rzeczywistej prędkości pojazdu (V_poj) i rzeczywistym opóźnieniu pojazdu (A_poj ).

Dodatkowymi informacjami są informacje o załączeniu hamulca elektrodynamicznego,

sygnalizacja zwiększonej masy wagonów z czujników ugięcia, gotowości hamulca ED wózków napędnych oraz sygnał o wystappieniu poślizgu osi wózków napędnych.

Podczas wstępnych prac projektowych zostały przeprowadzone symulacyjne obliczenia jazdy i hamowania elektrycznego zespołu trakcyjnego $\mathrm{z}$ napędem asynchronicznym. Jeden $z$ wykresów symulacji jazdy i zużycia energii przedstawiono na rysunku 5, ilustrującym uzyskane wartości prądu sieci, mocy chwilowej i zużytej energii przy napięciu sieci trakcyjnej 3000V. Ilustruje on możliwości odzysku energii podczas typowego cyklu rozruchu i hamowania zespołu trakcyjnego.

\section{Jazdy próbne}

Po przeprowadzonej modernizacji, elektryczny zespół trakcyjny EN57 AKM przeszedł pomyślnie testy stacjonarne i ruchowe. Zakres prób i badań obejmował przede wszystkim sprawdzenia układów oraz urządzeń decydujących o bezpieczeństwie ruchu i bezpieczeństwie przewożonych pasażerów, wymagane do uzyskania świadectwa dopuszczenia do eksploatacji typu pojazdu kolejowego, tj. badania:

- układów sterowania,

- układów hamulca,

- spokojności biegu pojazdu (do oceny możliwości zwiększenia prędkości maksymalnej zespołu trakcyjnego)

- kompatybilności elektromagnetycznej,

- właściwości akustycznych (hałasu wewnętrznego i zewnętrznego),

- właściwości trakcyjnych i gęstości pola magnetycznego.

Badania właściwości jezdnych pozwoliły na podwyższenie wartości prędkości maksymalnej ezt do $120 \mathrm{~km} / \mathrm{h}$.

Podczas jazd próbnych dokonywano rejestracji parametrów systemu zasilania. Na kolejnych rysunkach przedstawiono wykresy wartości prądu i mocy falowników podczas przejazdu na odcinku Tarnów - Bochnia, zarejestrowane na pokładzie ezt EN5 7AKM nr 1572.

Na rysunku 6 przedstawiono wartości napięcia sieci trakcyjnej, chwilowych wartości mocy pobieranej/rekuperowanej przez falowniki, chwilowych wartości prądu sieci pobieranego przez falowniki oraz prędkości jazdy w funkcji czasu. Celem próby było sprawdzenie funkcjonowania układów w czasie kolejnych cykli rozruch - hamowanie $\mathrm{z}$ wykorzystaniem hamowania ED i EP. Układ płynnie przełączał się z trybu napędowego w tryb hamowania odzyskowego. 


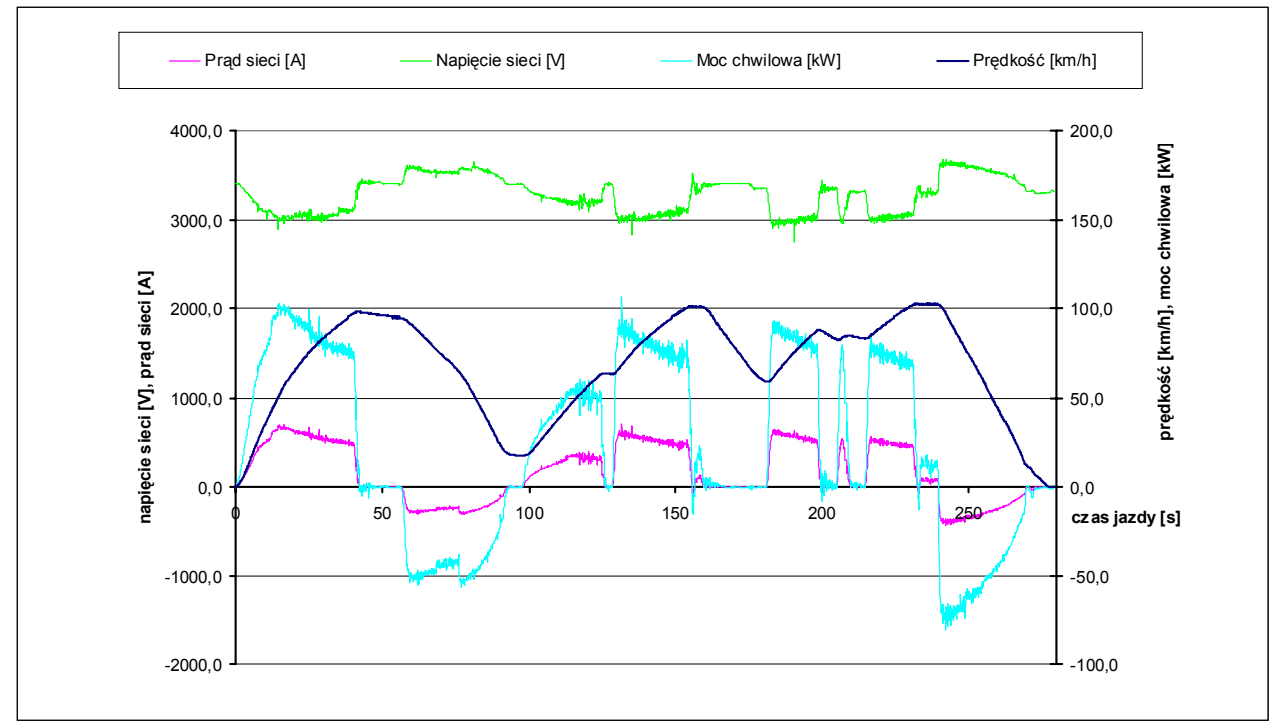

Rys. 6. Przebiegi zarejestrowane podczas badań wstępnych

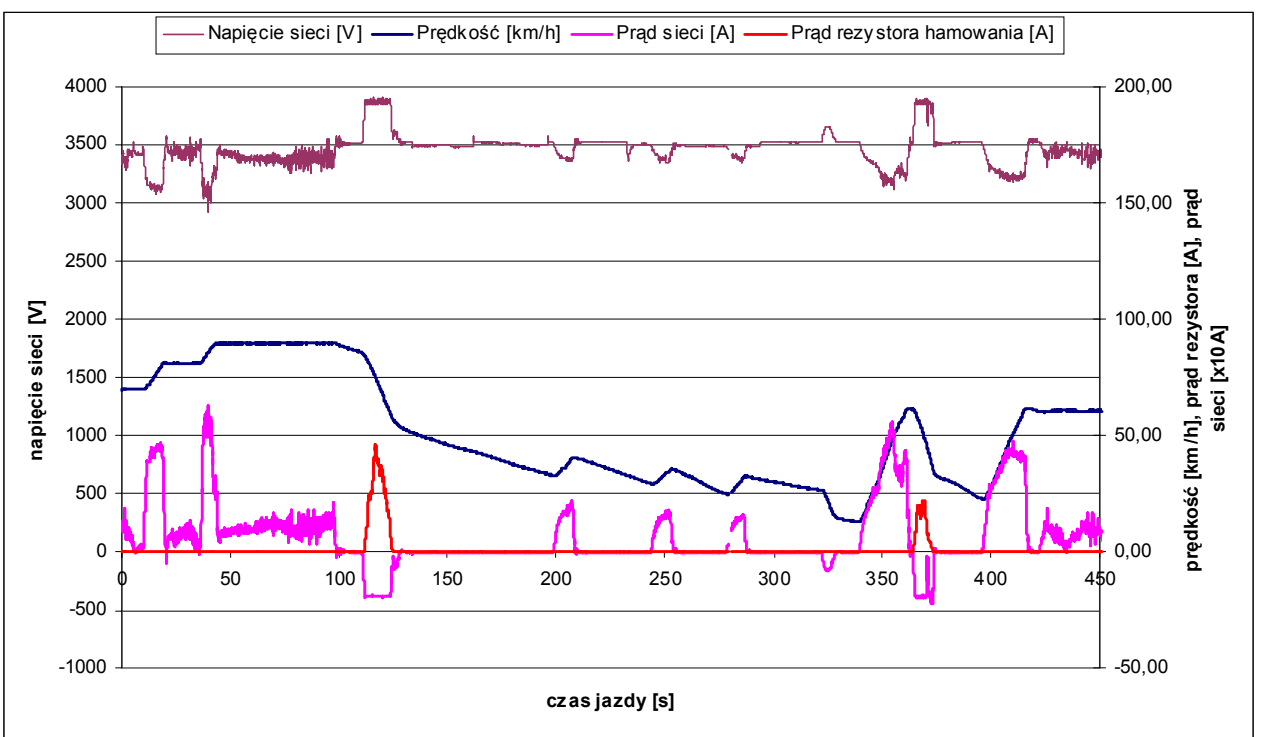

Rys. 7 Przebiegi podczas przekraczania maksymalnego napięcia rekuperacji.

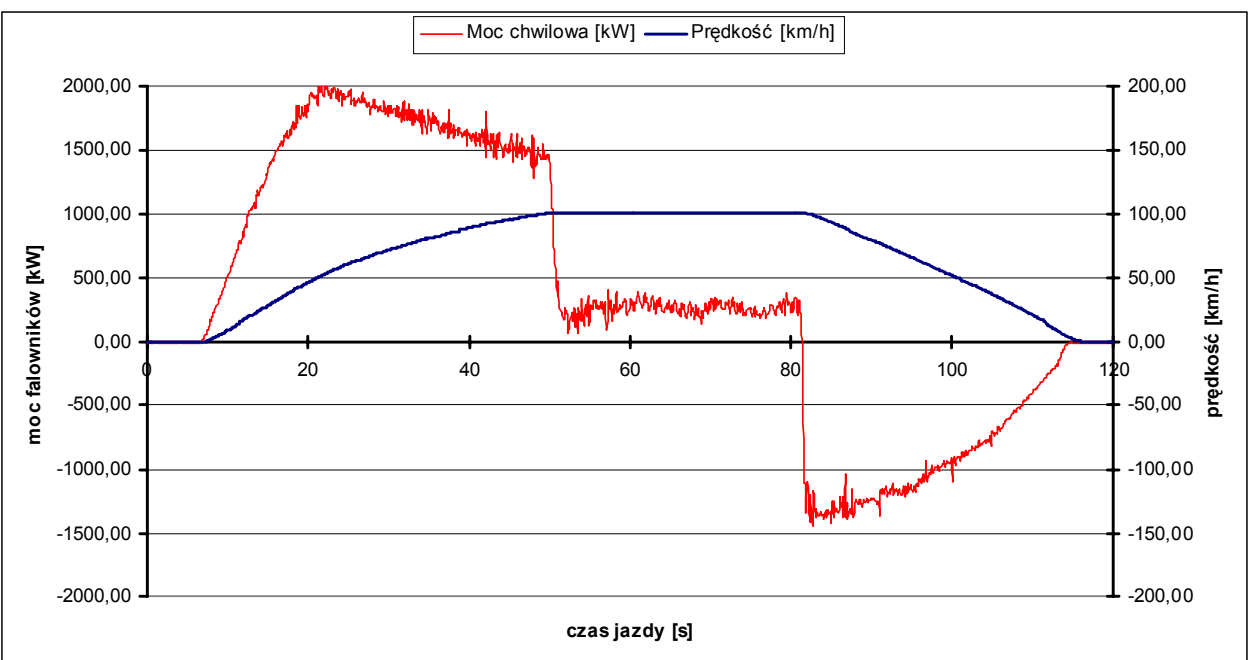

Rys. 8 Przebiegi podczas forsownego rozruchu, jazdy z ustaloną prędkością i hamowania odzyskowego.

Rysunek 7 przedstawia wartości prądów i napieć w sytuacji, gdy napięcie sieci jezdnej dochodzi do wartości maksymalnej (3900V) i następuje załączenie rezystora hamowania. Widać to podczas gwałtownego hamowania pod koniec drugiej i szóstej minuty jazdy, wówczas wartość prądu rezystora osiaga wartości wyższe niż wartość prądu zwracanego do sieci jezdnej.
Na rysunku 8 przedstawiono wykres mocy pobieranej przez ezt podczas forsownego rozruchu, jazdy z ustaloną prędkością i hamowania odzyskowego. Podczas rozruchu i jazdy ezt pobrał $20,4 \mathrm{kWh}$, podczas hamowania system przesłał do sieci $8,4 \mathrm{kWh}$. Całkowite zużycie energii w tym cyklu wyniosło $12,0 \mathrm{kWh}$ co daje aktywność zwrotu energii na poziomie ok. 41\% w rzeczywistych warunkach eksploatacyjnych. 


\section{Podsumowanie}

Zmodernizowanie układu napędowego w elektrycznych zespołach trakcyjnych serii EN/ED/EW poprzez zastosowanie układów napędowych prądu przemiennego $\mathrm{z}$ hamowaniem elektrodynamicznym (wraz z jego współpracą $\mathrm{z}$ hamowaniem pneumatycznym) to nowość zrealizowana w krajowych zespołach, dająca możliwość wykorzystania charakterystyk trakcyjnych $w$ pełnym zakresie realizowanych prędkości. Jednak zasadnicze korzyści wynikające z zastosowania hamowania elektrodynamicznego to:

- mniejsze zużycie energii elektrycznej (rozruch, rekuperacja),

- mniejsze zużycie klocków hamulcowych (hamowanie elektrodynamiczne),

- mniejsze zużycie obręczy (hamowanie elektrodynamiczne),

- zwiększenie opóźnienia hamowania,

- niższe koszty eksploatacji,

- obniżenie wartości wskaźnika LCC
Przedstawione wyżej efekty mają charakter korzyści społecznych, których skala - przy masowym upowszechnieniu omawianego rozwiązania - będzie ekonomicznie znacząca.

Modernizacja taboru jako proces pozwala na poprawienie istotnych parametrów technicznych znacznie szybciej i przy mniejszych nakładach niż zakupu nowego taboru. W procesie eksploatacji wymiana taboru na nowy i modernizacja taboru już eksploatowanego powinny być realizowane równolegle. Można mieć nadzieję że tak przygotowana modernizacja nie zakończy się na niewielkiej liczbie zespołów i będzie kontynuowana zarówno na zamówienie PKP „Przewozy Regionalne”, ale także dla spółek kolejowych powoływanych przez Urzędy Marszałkowskie. 